\title{
POTENSI KOMBINASI BAKTERI DAN JAMUR SELULOLITIK PADA FERMENTASI BEKATUL TERHADAP KANDUNGAN SERAT KASAR DAN PROTEIN KASAR
}

\section{THE POTENTIAL COMBINATION OF CELLULOLYTIC BACTERIA AND FUNGI ON THE RICE BRAN FERMENTED ON THE CRUDE FIBER AND CRUDE PROTEIN CONTENT}

\author{
Widya Paramita Lokapirnasari ${ }^{1 *}$, Agus Setiawan $^{2}$, dan Soetji Prawesthirini ${ }^{3}$ \\ ${ }^{1}$ Departemen Ilmu Peternakan, Fakultas Kedokteran Hewan, Universitas Airlangga, Surabaya, 60115 \\ ${ }^{2}$ Nabila Klinik, Kediri, 64211 \\ ${ }^{3}$ Departemen Kesehatan Masyarakat Veteriner, Fakultas Kedokteran Hewan, Universitas Airlangga, \\ Surabaya, 60115
}

Submitted: 11 June 2015, Accepted: 7 September 2015

\section{INTISARI}

Penelitian ini bertujuan untuk mengetahui kandungan serat kasar dan protein kasar pada bekatul padi yang difermentasi dengan bakteri selulolitik dan jamur selulolitik. Rancangan penelitian yang digunakan adalah Rancangan Acak Lengkap pola searah dengan sepuluh perlakuan dan masing-masing perlakuan dilakukan 3 kali ulangan. Ke sepuluh perlakuan tersebut adalah $\mathrm{P}_{0}: 250 \mathrm{~g}$ bekatul $+3 \%$ tetes + Bakteri (B) 0\% + Jamur (J) 0\%; $\mathrm{P}_{1}: 250 \mathrm{~g}$ bekatul $+3 \%$ tetes $+\mathrm{B} .10 \%+\mathrm{J} .10 \% ; \mathrm{P}_{2}: 250 \mathrm{~g}$ bekatul $+3 \%$ tetes + B.20\% + J.10\%; $\mathrm{P}_{3}: 250 \mathrm{~g}$ bekatul $+3 \%$ tetes + B.30\% + J.10\%; $\mathrm{P}_{4}: 250 \mathrm{~g}$ bekatul $+3 \%$ tetes + B. $10 \%+$ J.20\%; P5: $250 \mathrm{~g}$ bekatul $+3 \%$ tetes + B.20\% + J.20\%; P6: $250 \mathrm{~g}$ bekatul $+3 \%$ tetes + B. $30 \%+$ J.20\%; $\mathrm{P}_{7}: 250 \mathrm{~g}$ bekatul $+3 \%$ tetes + B. $10 \%+\mathrm{J} .30 \% ; \mathrm{P}_{8}: 250 \mathrm{~g}$ bekatul $+3 \%$ tetes + B.20\% + J.30\%; $\mathrm{P}_{9}: 250 \mathrm{~g}$ bekatul $+3 \%$ tetes + B.30\% + J.30\%. Setelah dilakukan fermentasi selama 7 hari, dilakukan analisis proksimat. Data yang diperoleh selanjutnya diuji dengan analisis variansi, dilanjutkan dengan uji Duncan's Multiple Range Test. Hasil penelitian menunjukkan bahwa bakteri selulolitik dan jamur selulolitik dapat menurunkan kandungan serat kasar pada bekatul pada perlakuan $\mathrm{P}_{2}(28,96 \%), \mathrm{P}_{3}(29,34 \%), \mathrm{P}_{8}(29,53 \%)$, $\mathrm{P}_{4}(29,65 \%), \mathrm{P}_{7}(30,23 \%), \mathrm{P}_{6}(30,37 \%), \mathrm{P}_{9}(30,58 \%)$ yang berbeda nyata $(\mathrm{P}<0,05)$ dengan perlakuan $\mathrm{P}_{5}$ $(31,10 \%), \mathrm{P}_{1}(31,98 \%), \mathrm{P}_{0}(34,11 \%)$, serta dapat meningkatkan kandungan protein kasar pada perlakuan $\mathrm{P}_{2}(13,97 \%), \mathrm{P}_{5}(12,87 \%), \mathrm{P}_{3}(12,84 \%), \mathrm{P}_{8}(12,74 \%)$ yang berbeda $(\mathrm{P}<0,05)$ dengan perlakuan $\mathrm{P}_{7}(12,71 \%)$, $P_{6}(12,44 \%), P_{4}(12,36 \%), P_{9}(12,27 \%), P_{1}(12,25 \%), P_{0}(10,9 \%)$.

(Kata kunci: Acidothermus cellulolyticus, Aspergillus terreus, Bekatul, Fermentasi, Protein kasar, Serat kasar)

\section{ABSTRACT}

Aim of the research was to investigate the crude fibre and crude protein contents of rice bran which fermented using Acidothermus cellulolyticus and Aspergillus terreus. This study was design using Completely Randomized Design with ten treatments and three replications in each replicate. The ten treatment groups were $250 \mathrm{~g}$ rice bran $+3 \%$ molasses $\left(P_{0}\right) ; 250 \mathrm{~g}$ rice bran $+3 \%$ molasses $+10 \%$ bacteria $(B)+10 \%$ fungi $(F)\left(P_{1}\right) ; 250$ g rice bran $+3 \%$ molasses $+20 \% B+10 \% F\left(P_{2}\right) ; 250$ g rice bran $+3 \%$ molasses $+30 \% B+10 \% F\left(P_{3}\right) ; 250$ g rice bran $+3 \%$ molasses $+10 \% B+20 \% F\left(P_{4}\right) ; 250$ g rice bran + $3 \%$ molasses $+20 \% B+20 \% F\left(P_{5}\right) ; 250$ g rice bran $+3 \%$ molasses $+30 \% B+20 \% F\left(P_{6}\right) ; 250$ g rice bran $+3 \%$ molasses $+10 \% B+30 \% F\left(P_{7}\right) ; 250$ g rice bran $+3 \%$ molasses $+20 \% B+30 \% F\left(P_{8}\right) ; 250$ g rice bran $+3 \%$ molasses $+30 \% B+30 \% F\left(P_{9}\right)$. Proximate analysis were performed after rice bran fermented for seven days. The data were analyzed with Analysis of Variance followed by Duncan's Multiple Range Test. The result showed that the effect of Acidothermus cellulolyticus and Aspergillus terreus could decrease crude fibre of rice bran, $P_{2}$ (28.96\%), $P_{3}(29.34 \%), P_{8}(29.53 \%), P_{4}(29.65 \%), P_{7}(30.23 \%), P_{6}$ (30.37\%), $P_{9}(30.58 \%)$ but were significantly higher $(P<0.05)$ than $P_{5}(31.10 \%), P_{1}(31.98 \%), P_{0}(34.11 \%)$, could increase crude protein of rice brand, $P_{2}(13.97 \%), P_{5}(12.87 \%), P_{3}(12.84 \%), P_{8}(12.74 \%)$ but were significantly higher $(P<0.05)$ than $P_{7}(12.71 \%), P_{6}(12.44 \%), P_{4}(12.36 \%), P_{9}(12.27 \%), P_{1}(12.25 \%), P_{0}$ (10.9\%).

(Key words: Acidothermus cellulolyticus, Aspergillus terreus, Crude fibre, Crude protein, Fermented, Rice bran)

\footnotetext{
* Korespondensi (corresponding author):

Telp. +62 85731469579

E-mail: wp_lokapirnasari@yahoo.com
} 


\section{Pendahuluan}

Usaha meningkatkan kualitas pakan tidak terlepas dari pengolahan pakan. Penggunaan bahan pakan impor mengakibatkan tingginya harga pakan. Jika hal ini berlangsung terus menerus, maka banyak peternak yang akan mengalami kerugian. Hal tersebut dapat diminimalkan dengan adanya alternatif bahan pakan lokal yang bersifat nonkonvensional dan tidak bersaing dengan kebutuhan manusia, harganya murah, tetapi mempunyai kandungan nutrisi yang cukup untuk ternak (Hanafi, 2001).

Bahan pakan alternatif untuk ternak yang dapat digunakan untuk menekan harga pakan adalah dengan memanfaatkan limbah pertanian. Namun limbah pertanian tersebut pada umumnya memiliki faktor pembatas, yaitu kandungan protein yang rendah dan serat yang tinggi. Hal ini menyebabkan pemanfaatan limbah pertanian sebagai pakan tidak mampu memenuhi kecukupan nutrisi untuk produksi dan hanya sebagai pakan basal saja (Harfiah, 2010). Pada limbah tanaman tua, pada umumnya telah mengalami proses lignifikasi lanjut di mana terjadi ikatan selulosa oleh lignin dalam bentuk kristal lignoselulosa. Lignoselulosa terdiri dari selulosa, hemiselulosa dan lignin. Selulosa merupakan penyusun dinding sel tanaman yang sukar didegradasi karena monomer glukosanya dihubungkan dengan ikatan $\beta$-(1.4) (Ekinci et al., 2002; Rasjid, 2012).

Limbah pertanian yang tersedia sepanjang tahun seperti bekatul, ampas tahu, dan onggok pada umumnya berkualitas rendah dari segi kandungan protein dan juga mengandung serat yang tinggi (Rakhmani, 2005). Bekatul merupakan bahan pakan limbah pertanian yang banyak dipakai untuk pakan ternak, mudah didapat dan harganya relatif murah karena bekatul merupakan produk sampingan dari penggilingan padi. Keterbatasan pemanfaatan bekatul sebagai campuran pakan unggas adalah kandungan proteinnya yang rendah, serat kasar yang tinggi dan adanya asam fitat yang mampu mengikat mineral $\mathrm{Ca}$ serta protein menjadi garam fitat dan fitat protein sehingga menurunkan kemanfaatannya oleh unggas, dengan demikian bekatul memiliki kecernaan yang rendah (Sujono, 2001).

Usaha memperbaiki nilai gizi suatu bahan pakan dapat diberikan perlakuan penambahan pakan tambahan dengan kualitas tinggi yang akan meningkatkan konsumsi nutrien dan kecernaan protein (Astuti, 2009). Salah satu cara untuk meningkatkan nilai nutrisi dan kecernaan bekatul serta aman penggunaannya adalah dengan cara biologis yaitu dengan fermentasi yang menggunakan Acidothermus cellulolyticus dan Aspergillus terreus yang berasal dari cairan rumen sapi.

Rumen merupakan lingkungan yang sangat baik untuk pertumbuhan mikrobia yang terdiri dari bakteri, jamur dan protozoa. Mikrobia tersebut di dalam retikulo-rumen mempunyai peranan penting dalam proses fermentasi pakan (Akoso, 1996). Di antara bakteri-bakteri tersebut termasuk di dalamnya bakteri yang dapat mencerna serat kasar (Arora, 1989).

Acidothermus cellulolyticus menghasilkan enzim selulase yang dapat digunakan untuk mendegradasi selulosa pada tanaman. Acidothermus cellulolyticus akan dominan apabila pakan utama ternak berupa serat kasar. Acidothermus cellulolyticus ini menghasilkan enzim selulase yang dapat mengkatalisis reaksi pemutusan ikatan 1,4 $\beta$ glukosida dalam selulosa (Enrari, 1983).

Selain bakteri ada juga jamur di dalam rumen yang sangat bermanfaat dalam mencerna pakan berserat. Salah satunya adalah Aspergillus terreus yang dapat menghasilkan enzim selulase yang dapat memecah polisakarida menjadi glukosa yang digunakan untuk pertumbuhan dan reproduksi (Bechara, 2006).

Pada umumnya Acidothermus cellulolyticus dan Aspergillus terreus memiliki peranan memecah bahan pakan berserat dan mensintesis asam-asam amino yang terdapat dalam komponen bahan pakan (Stewart, 1991), sehingga diharapkan penggunaan Acidothermus cellulolyticus dan Aspergillus terreus tersebut dapat meningkatkan nutrisi bekatul.

\section{Materi dan Metode}

\section{Materi}

Penelitian ini dilaksanakan di Laboratorium Departemen Peternakan, Fakultas Kedokteran Hewan, Universitas Airlangga, Surabaya. Bahan yang digunakan dalam penelitian ini adalah bekatul yang diperoleh dari daerah Blitar, Jawa Timur dan molasis (tetes), serta suspensi Acidothermus cellulolyticus dan Aspergillus terreus yang 
berasal dari isolasi dan identifikasi cairan rumen sapi. Isolat tersebut merupakan koleksi Lokapirnasari et al. (2009). Kemampuan selulolitik dapat dilihat dari pertumbuhan koloni pada media CMC padat dan mampu tumbuh pada media CMC cair. Pertumbuhan bakteri selulolitik pada media CMC cair dapat dilihat dari perubahan warna media yang menjadi keruh. Uji pada media CMC padat menunjukkan bahwa di sekitar koloni tampak daerah yang lebih terang dan daerah ini disebut sebagai zona terang (cleared zone). Kemampuan isolat tersebut tumbuh pada media selulosa membuktikan bahwa isolat tersebut mampu memanfaatkan selulosa sebagai salah satu sumber nutriennya. Bahan kimia untuk analisis protein kasar yang terdiri dari: tablet Kjeldahl, $\mathrm{H}_{2} \mathrm{SO}_{4}$ pekat, $\mathrm{NaOH} 40 \%$, Boric acid, indikator Metil-Red, Brom Cresol Green, $\mathrm{H}_{2} \mathrm{SO}_{4}$ 0,01 $\mathrm{N}$ dan aquadest. Bahan kimia untuk analisis serat kasar terdiri dari : $\mathrm{H}_{2} \mathrm{SO}_{4} 0,3 \mathrm{~N}, \mathrm{NaOH} 1,5 \mathrm{~N}, \mathrm{HCl} 0,3 \mathrm{~N}$, Aceton dan $\mathrm{H}_{2} \mathrm{O}$ panas.

\section{Tahap fermentasi bekatul}

Bahan bekatul dibagi secara acak menjadi 30 unit percobaan, masing-masing dengan berat sampel $250 \mathrm{~g}$. Tiap unit percobaan dicampur molasis 3\% dari berat bahan serta suspensi Acidothermus cellulolyticus dan Aspergillus terreus dari cairan rumen sapi sesuai level yang telah ditetapkan. Lama fermentasi pada penelitian ini ditetapkan berdasarkan penelitian pendahuluan yang telah dilaksanakan.

Bahan dicampur secara homogen dengan cara diaduk kemudian dimasukkan ke dalam kantong plastik berkode sesuai dengan perlakuan kemudian diikat dan difermentasi selama \pm 7 hari dalam kondisi fakultatif anaerob (Setyono et al., 2004). Perlakuan pada penelitian ini adalah sebagai berikut: $\mathrm{P}_{0}$ : bekatul + bakteri $0 \%+$ jamur $0 \%+$ molasis $3 \% ; \mathrm{P}_{1}$ : bekatul + bakteri 10\% + jamur $10 \%+$ molasis 3\%; $\mathrm{P}_{2}$ : bekatul + bakteri $20 \%+$ jamur $10 \%+$ molasis 3\%; $\mathrm{P}_{3}$ : bekatul + bakteri $30 \%$ + jamur $10 \%+$ molasis 3\%; $\mathrm{P}_{4}$ : bekatul + bakteri $10 \%+$ jamur $20 \%+$ molasis $3 \%$; $P_{5}$ : bekatul + bakteri $20 \%+$ jamur $20 \%+$ molasis $3 \%$; $\mathrm{P}_{6}$ : bekatul + bakteri $30 \%+$ jamur $20 \%+$ molasis 3\%; $\mathrm{P}_{7}$ : bekatul + bakteri $10 \%+$ jamur $30 \%+$ molasis 3\%; $\mathrm{P}_{8}$ : bekatul + bakteri $20 \%$ + jamur 30\% + molasis 3\%; P9: bekatul + bakteri $30 \%+$ jamur $30 \%+$ molasis $3 \%$.

\section{Analisis proksimat}

Analisis proksimat serat kasar dan protein kasar pada semua perlakuan, dilakukan setelah difermentasi selama \pm 7 hari (Setyono et al., 2004).

\section{Analisis data}

Data yang diperoleh selanjutnya dianalisis menggunakan analisis variansi pola searah (One Way Anova). Apabila terdapat perbedaan yang nyata dilanjutkan dengan uji jarak berganda Duncan dengan signifikansi 5\% (Kusriningrum, 2008).

\section{Hasil dan Pembahasan}

Hasil analisis statistik menunjukkan bahwa penambahan Acidothermus cellulolyticus dan Aspergillus terreus pada fermentasi bekatul menurunkan kandungan serat kasar dan meningkatkan protein kasar bekatul $(P<0,05)$.

Hasil analisis proksimat serat kasar terjadi penurunan kandungan serat kasar dari $34,11 \%\left(P_{0}\right)$ menjadi $28,96 \%\left(P_{2}\right)$ yang tidak berbeda dengan 29,23\% $\left(P_{3}\right), 29,49 \%\left(P_{8}\right)$, $29,65 \% \quad\left(P_{4}\right), 30,23 \% \quad\left(P_{7}\right), 30,37 \% \quad\left(P_{6}\right)$ $30,58 \%\left(P_{9}\right)$ (Tabel 1). Penurunan kandungan serat kasar ini disebabkan karena Acidothermus cellulolyticus dan Aspergillus terreus mempunyai kemampuan mendegradasi bahan organik terutama selulosa karena adanya enzim selulase yang dihasilkan oleh Acidothermus cellulolyticus dan Aspergillus terreus yang dapat memecah serat kasar menjadi glukosa (Stewart, 1991).

Persentase level Acidothermus cellulolyticus dan Aspergillus terreus yang tinggi dan tidak diimbangi dengan kandungan nutrisi yang sesuai dapat menyebabkan aktivitas Acidothermus cellulolyticus dan Aspergillus terreus untuk tumbuh selama proses fermentasi akan menjadi terhambat. Pada perlakuan $\mathrm{P}_{1}(31,98 \%)$ jumlah level Acidothermus cellulolyticus dan Aspergillus terreus yang lebih sedikit sehingga untuk melakukan aktivitas dalam mendegradasi selulosa belum optimal dan pada perlakuan $\mathrm{P}_{5} \quad(31,10 \%)$ jumlah level Acidothermus cellulolyticus dan Aspergillus terreus yang lebih banyak tidak sebanding dengan sumber nutrisi yang tersedia sehingga menyebabkan Acidothermus cellulolyticus dan Aspergillus terreus belum mampu untuk menghasilkan 
Tabel 1. Rerata kandungan serat kasar bekatul setelah fermentasi (average of crude fiber content after fermentation)

\begin{tabular}{|c|c|c|}
\hline $\begin{array}{c}\text { Level Acidothermus cellulolyticus dan } \\
\text { Aspergillus terreus }\end{array}$ & $\begin{array}{l}\text { Serat kasar }(\%) \\
\text { (crude fiber (\%)) }\end{array}$ & $\begin{array}{l}\text { Transformasi }(\arcsin \sqrt{y}) \\
(\text { transformation }(\arcsin \sqrt{y}))\end{array}$ \\
\hline $\mathrm{P}_{0}(\mathrm{~B} .0 \%+\mathrm{J} .0 \%)$ & $34,11 \pm 0,14$ & $35,73 \pm 0,13^{a}$ \\
\hline$P_{1}(\mathrm{~B} .10 \%+\mathrm{J} .10 \%)$ & $31,98 \pm 0,49$ & $34,43 \pm 0,30^{\mathrm{b}}$ \\
\hline$P_{5}($ B. $20 \%+$ J.20\%) & $31,10 \pm 0,61$ & $33,89 \pm 0,37^{\mathrm{bc}}$ \\
\hline$P_{9}(B .30 \%+J .30 \%)$ & $30,58 \pm 0,19$ & $33,57 \pm 0,12^{\mathrm{bcd}}$ \\
\hline $\mathrm{P}_{6}(\mathrm{~B} .30 \%+\mathrm{J} .20 \%)$ & $30,37 \pm 0,33$ & $33,44 \pm 0,05^{\mathrm{bcd}}$ \\
\hline$P_{7}(B .10 \%+J .30 \%)$ & $30,23 \pm 0,50$ & $33,35 \pm 0,31^{\mathrm{bcd}}$ \\
\hline $\mathrm{P}_{4}(\mathrm{~B} .10 \%+\mathrm{J} .20 \%)$ & $29,65 \pm 0,77$ & $32,98 \pm 0,48^{\mathrm{cd}}$ \\
\hline$P_{8}(B .20 \%+J .30 \%)$ & $29,49 \pm 0,50$ & $32,89 \pm 0,31^{\mathrm{cd}}$ \\
\hline$P_{3}(B .30 \%+J .10 \%)$ & $29,23 \pm 0,57$ & $32,72 \pm 0,36^{\mathrm{cd}}$ \\
\hline$P_{2}(B .20 \%+J .10 \%)$ & $28,96 \pm 0,28$ & $32,55 \pm 0,18^{d}$ \\
\hline
\end{tabular}

Tabel 2. Rerata kandungan protein kasar bekatul setelah fermentasi (average of crude protein content after fermentation)

\begin{tabular}{ccc}
\hline \hline $\begin{array}{c}\text { Level Acidothermus cellulolyticus dan } \\
\text { Aspergillus terreus }\end{array}$ & $\begin{array}{c}\text { Protein kasar }(\%) \\
(\text { crude protein }(\%))\end{array}$ & $\begin{array}{c}\text { Transformasi }(\sqrt{ } \mathrm{y}) \\
(\text { transformation }(\sqrt{y}))\end{array}$ \\
\hline $\mathrm{P}_{2}(\mathrm{~B} .20 \%+\mathrm{J} .10 \%)$ & $13,97 \pm 0,45$ & $3,74 \pm 0,06^{\mathrm{a}}$ \\
$\mathrm{P}_{5}(\mathrm{~B} .20 \%+\mathrm{J} .20 \%)$ & $12,87 \pm 0,18$ & $3,59 \pm 0,02^{\mathrm{ab}}$ \\
$\mathrm{P}_{3}(\mathrm{~B} .30 \%+\mathrm{J} .10 \%)$ & $12,84 \pm 0,00$ & $3,58 \pm 0,00^{\mathrm{ab}}$ \\
$\mathrm{P}_{8}(\mathrm{~B} .20 \%+\mathrm{J} .30 \%)$ & $12,74 \pm 0,06$ & $3,57 \pm 0,01^{\mathrm{ab}}$ \\
$\mathrm{P}_{7}(\mathrm{~B} .10 \%+\mathrm{J} .30 \%)$ & $12,71 \pm 0,34$ & $3,56 \pm 0,05^{\mathrm{b}}$ \\
$\mathrm{P}_{6}(\mathrm{~B} .30 \%+\mathrm{J} .20 \%)$ & $12,44 \pm 0,18$ & $3,53 \pm 0,02^{\mathrm{b}}$ \\
$\mathrm{P}_{4}(\mathrm{~B} .10 \%+\mathrm{J} .20 \%)$ & $12,36 \pm 0,55$ & $3,51 \pm 0,08^{\mathrm{b}}$ \\
$\mathrm{P}_{9}(\mathrm{~B} .30 \%+\mathrm{J} .30 \%)$ & $12,27 \pm 0,00$ & $3,50 \pm 0,00^{\mathrm{b}}$ \\
$\mathrm{P}_{1}(\mathrm{~B} .10 \%+\mathrm{J} .10 \%)$ & $12,25 \pm 0,00$ & $3,50 \pm 0,00^{\mathrm{b}}$ \\
$\mathrm{P}_{0}(\mathrm{~B} .0 \%+\mathrm{J} .0 \%)$ & $10,90 \pm 0,21$ & $3,30 \pm 0,03^{\mathrm{c}}$ \\
\hline $\mathrm{a}, \mathrm{b}, \mathrm{c}$ Superskrip berbeda pada kolom yang sama menunjukkan perbedaan yang nyata $(\mathrm{P}<0,05)($ different superscripts \\
\multicolumn{2}{c}{ at the same column indicate significant differences $(P<0.05))}$.
\end{tabular}

enzim selulase secara maksimal. Hardjo et al. (1989) menyatakan bahwa ketersediaan nutrisi yang lebih besar daripada populasi bakteri dan jamur dapat menyebabkan laju pertumbuhan bakteri dan jamur optimal.

Hasil analisis proksimat protein kasar terjadi peningkatan kandungan protein kasar bekatul yang difermentasi dengan menggunakan Acidothermus cellulolyticus dan Aspergillus terreus dari 10,90\% ( $\left.\mathrm{P}_{0}\right)$ menjadi $13,97 \%\left(\mathrm{P}_{2}\right)$ tidak berbeda dengan $12,87 \%$ $\left(P_{5}\right), 12,84 \%\left(P_{3}\right), 12,74 \%\left(P_{8}\right)$ (Tabel 2). Hal ini disebabkan peningkatan aktivitas Acidothermus cellulolyticus dan Aspergillus terreus dalam mengikat $\mathrm{N}$ sebagai bahan dasar untuk sintesis protein, sehingga peningkatan kadar nitrogen ini sangat menguntungkan bakteri dan jamur untuk melakukan pertumbuhan dan melakukan aktivitas secara optimal sehingga kadar protein kasar bekatul meningkat lebih tinggi dibandingkan dengan perlakuan lainnya karena bakteri dan jamur merupakan protein sel tunggal.

Peningkatan kandungan protein kasar juga dapat disebabkan karena adanya penurunan senyawa yang lain antara lain bahan ekstrak tanpa nitrogen (BETN) yang berasal dari serat kasar terfermentasi dan menghasilkan gas yang hilang. Hasil penelitian menunjukkan bahwa penggunaan isolat selulolitik tersebut dapat menurunkan kandungan serat kasar. Bila nitrogen meningkat maka menunjukkan unsur karbon yang turun. Perkembangan dari mikrobia tergantung pada karbon yang tersedia, dengan meningkatnya jumlah mikrobia tersebut maka terjadi kompetisi di antara mikrobia untuk mendapatkan karbon, sehingga ketersediaan karbon menjadi faktor pembatas (Rifqiyah, 2005).

Acidothermus cellulolyticus dan Aspergillus terreus mampu menghasilkan enzim protease yang akan merombak protein 
menjadi peptida sederhana, kemudian peptida ini akan dirombak menjadi asamasam amino (Anggorodi, 1994). Asam-asam amino inilah yang akan dimanfaatkan oleh mikrobia untuk memperbanyak diri. Meningkatnya jumlah koloni Acidothermus cellulolyticus dan Aspergillus terreus selama proses fermentasi secara tidak langsung dapat meningkatkan kandungan protein kasar karena bakteri dan jamur merupakan protein sel tunggal (Wuryantoro, 2000).

Persentase level Acidothermus cellulolyticus dan Aspergillus terreus yang tinggi dan tidak diimbangi dengan kandungan nutrisi yang sesuai dapat menyebabkan aktivitas Acidothermus cellulolyticus dan Aspergillus terreus untuk tumbuh selama proses fermentasi akan menjadi terhambat. Tanpa kandungan nutrisi yang lengkap perombakan protein tidak dapat berjalan optimal karena Acidothermus cellulolyticus dan Aspergillus terreus tidak akan hidup dan berkembang dengan baik.

\section{Kesimpulan}

Penggunaan kombinasi Acidothermus cellulolyticus $20 \%$ + Aspergillus terreus $10 \%$ memberikan nilai penurunan serat kasar serta peningkatan kandungan protein kasar terbaik pada bekatul yang difermentasi.

\section{Daftar Pustaka}

Akoso, B. T. 1996. Kesehatan Sapi. Kasinius. Yogyakarta.

Astuti, A., A. Agus, dan S. P. S. Budi. 2009. Pengaruh penggunaan high quality feed supplement terhadap konsumsi dan kecernaan nutrien sapi perah awal laktasi. Buletin Peternakan 33: 81-87.

Anggorodi, R. 1994. Ilmu Makanan Ternak Dasar. Gramedia Pustaka Utama, Jakarta.

Arora, S. P. 1989. Pencernaan Mikrobia Pada Ruminansia. Gadjah Mada Press, Yogyakarta.

Bechara, M. A. 2006. Enzyme Production. www.fungal enzyme production and use.htm. Diakses pada 23 March 2010.

Ekinci, M. S., J. C. Martin and H. J. Flint. 2002. Expression of a cellulase gene, ce1A, from the rumen fungus Neocallimastix patriciarum in Streptococcus bovis by means of promoter fusions. $\mathrm{J}$. Biotechnol. Lett. 24: 735-741.
Enrari, T. M. 1983. Microbial Cellulase. In: Microbial Enzymes and Biotechnology. W. M. Forgaty (ed). Appl. Sci. Publishing, New York.

Hanafi, N. D. 2001. Alternatif baru dalam peningkatan kualitas pakan untuk ternak. Makalah falsafah Sains (PPs 702). Program Pascasarjana /S3 IP3. http://www.rudyct.tripod.com/indiv.200 $1 /$ nev.htm. Diakses pada pada 23 Maret 2010.

Hardjo, S., N. S. Indrasti, dan T. Bantacut. 1989. Biokonversi: Pemanfaatan Limbah Industri Pertanian. PAUPangan dan Gizi, Institut Pertanian Bogor, Bogor.

Harfiah. 2010. Optimalisasi penggunaan jerami padi sebagai pakan ruminansia. Disertasi, PPS Universitas Hasanuddin, Makassar.

Kusriningrum. 2008. Dasar Perancangan Percobaan dan Rancangan Acak Lengkap. Universitas Airlangga, Surabaya.

Lokapirnasari, W. P., M. Lamid, dan H. Setyono. 2009. Rekayasa Nutrien High Quality Feed (HFQ) untuk Meningkatkan Efisiensi Pakan, Kualitas Produksi dan Sistem Imunitas pada Ayam Petelur yang di Vaksin Al. Fakultas Kedokteran Hewan, Universitas Airlangga, Surabaya.

Rakhmani, S. I. 2005. Peningkatan nilai gizi bahan pakan dari limbah pertanian melalui fermentasi. http://peternakan.litbang.deptan.go.id/ ?q=node/778. Diakses pada 23 Maret 2010.

Rasjid, S. 2012. The Great Ruminant Nutrisi, Pakan dan Manajemen Produksi. Cetakan Kedua. Brilian Internasional, Surabaya.

Rifqiyah, N. 2005. Pengaruh pemberian probiotik pada jerami padi terhadap kandungan protein kasar dan serat kasar. Skripsi Fakultas Kedokteran Hewan, Universitas Airlangga, Surabaya.

Setyono, H., M. Lamid, Tri Nurhajati, dan A. Al-Arif. 2004. Penggunaan probiotik pada jerami padi suatu upaya penyediaan pakan ternak ruminansia yang berkualitas. Laporan Penelitian Dik Rutin, Lembaga Penelitian Universitas Airlangga, Surabaya. 
Stewart, C. S. 1991. The rumen bacteria. In: Rumen Microbial Metabolism and Ruminant Digestion. J. P. Jouany (ed). Institut National De La Recherche Agronomique, Paris, France.

Sujono. 2001. Tampilan produksi telur, produksi karkas dan kualitas semen ayam Arab yang diberi pakan mengandung berbagai aras bekatul fermentasi dengan Rhizopus oligosporus. Disertasi Program Pasca Sarjana, Universitas Airlangga, Surabaya.

Widayati, dan Y. Widalestari. 1996. Limbah untuk Pakan Ternak. Trubus Agrisarana, Jakarta.
Widyarti. 1991. Pengaruh Penambahan Ragi Tape dan Lama Inkubasi Terhadap Nilai Nutrisi Bekatul Sebagai Pakan Ternak. Fakultas Peternakan, Universitas Brawijaya, Malang.

Wuryantoro, S. 2000. Kandungan Protein Kasar dan Serat Kasar Hay Padi Teramoniasi yang Difermentasi Dengan Cairan Rumen. Fakultas Kedokteran Hewan, Universitas Airlangga, Surabaya. 